Original Paper

\title{
新規な連続混合混練造粒乾燥システムによる打錠末の製造と成形
}

\section{Preparation of Granules for Tablet by a Novel Continuous Mixing, Kneading, Granulation and Drying System and Evaluation of Tablet Properties}

\author{
迳 隆伸 ${ }^{\mathrm{a} *}$, 田中 基大 ${ }^{\mathrm{a}}$, 浅井 直親 ${ }^{\mathrm{a}}$, 綿野 哲 ${ }^{\mathrm{b}}$ \\ Takanobu Tsuji, Motohiro Tanaka, Naochika Asai, Satoru Watano
}

Received 11 May 2016; Accepted 28 June 2016

In this study, a novel continuous manufacturing system composed of mixing, kneading, granulation, and drying has been developed and its performance was evaluated experimentally.

First of all, agitation torque during kneading process was continuously measured using different kinds of powder samples and binder liquid addition ratios, and state of liquid/powder mixture was analyzed. Residence time and hold-up of wet kneaded mass were also measured during the kneading process. Based on the results obtained, the optimum operating regions of screw agitation speed and powder feed rate were determined. Orally rapidly disintegrating tablets were then prepared by the granules made by the continuous system and properties of tablets were evaluated. It was found that the optimum binder addition rate could produce orally rapidly disintegrating tablets with favorable properties.

Keywords: Continuous manufacturing system, Agitation torque, Residence time, Rapidly disintegrating tablet

\section{1. 緒言}

近年，医薬品固形製剂の製造プロセスにおいて連続プ ロセスの検討が盛んに行われている。連続プロセスでは 各工程のプロセスデータの記録拈よびプロセス解析工学 （PAT）を用いることによって，安定した品質を有する 製品の製造が求められている1”。そのためには，製剂開 発時に QbD（Quality by Design）により工程が設計され, さらに厚生労働省や FDA などの規制当局の製造承認を 受けることが必要である2 ${ }^{2}$ 。QbD では品質は製品になっ てから検証するのではなく，製品設計によって製品に組

a 株式会社ダルトン パウダー・システム機器事業部 （广579-8014 大阪府東大阪市中石切町 7-1-45） Powder \& System Equipment Division, Dalton Co., Ltd. (1-45 7-chome, Nakaishikiri-cho, Higashiosaka, Osaka 5798014, Japan)

$b$ 大阪府立大学大学院 工学研究科 物質 - 化学系専攻 化学工 学分野

（于599-8531 大阪府堺市中区学園町 1-1）

Department of Chemical Engineering, Graduate School of Engineering, Osaka Prefecture University

(1 1-chome, Gakuen-cho, Naka-ku, Sakai, Osaka 599-8531, Japan)

*責任著者連絡先 ta-tsuji@dalton.co.jp
み込まれているべきだと一般的にいわれており ${ }^{3)}$ この 製品設計を行うには製造プロセス各工程をより深く理解 し, 実験計画法を用いてパラメー夕の運転範囲を特定し, デザインスペースを構築することが求められる。

本研究では, 新規に開発した連続混合混練造粒乾燥シ ステムにおいて $\mathrm{QbD}$ の考えに基づき, 重要工程パラメー 夕（CPP）と考える結合液添加割合と混練回転速度およ び粉体供給速度を変更し, 重要物質特性 (CMA) とし て挙げられる粒子径などの顆粒特性と錠剤硬度などの錠 剂特性への影響を調べることを目的とした。まずはじめ に, 結合液涯加率を変化させて, 混練時の擋汼トルクを 計測し, 固液充填状態の解析を行った。次に, 優れた錠 剂特性を持つ崩壊錠が成形可能な結合液添加率の範囲を 決定した。さらに, 混練部における湿潤粉体の滞留時間 及びホールドアップ量を測定し, 装置内部の粉体の充填 状態を調へ, 混練回転速度と粉体供給速度の運転可能範 囲を明らかにした。

\section{2. 実験装置および方法}

\section{1 固液充填状態の評価および処方} 固液充填状態の評価には湿潤粉体の擋汼時に発生する 


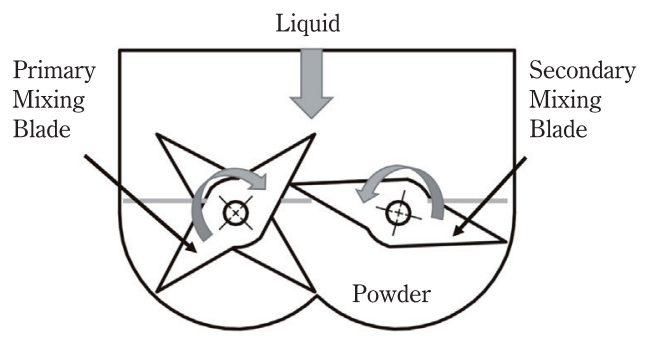

Fig. 1 Schematic diagram of Mixer Torque Rheometer

トルクを用いだ)。Fig. 1 に使用した装置 Mixer Torque Rheometer（以後 MTR と略称 Caleva 製 UK）の模式 図を示す。本測定機は擋找容器内（有効容量約 $150 \mathrm{~mL}$ ) に水平に逆回転する 2 種類の Mixing blade を備えている。 擋拌トルクは Mixing blade のシャフトに取り付けられた 歪計・変換機を介してリアルタイムでパーソナルコンピュー 夕にて収集する。

実験では MTR の擋找容器に粉体試料を投入する際に, 充填体積を一定にするため供給する質量を 10 30 g で 変化させた。その後精製水を添加し, Mixing blade 回転 速度 $50 \mathrm{rpm}$ で 30 秒間擋找混合を行った。その後 20 秒間 擋找し，その20秒間の Mixing blade のシャフトに作用す るトルクの平均值を擋找トルクとした。精製水の追加と トルク測定を繰り返し, 結合液添加率と擋找トルクの関 係を求めた。

粉体試料には崩壊錠の作製を目的としてアセトアミノ フェン (岩城製薬) 10\%，D-マンニット（マンニットP： 三菱フードテック） $75 \%$, 結晶セルロース（KG-802： 旭化成ケミカルズ） $10 \%$ ，低置換度ヒドロキシプロピル セルロース（L-HPC：信越化学工業）5\%を混合した 粉にバインダーとしてヒドロキシプロピルセルロース （HPC-L：日本曹達）を乾燥混合粉体に対して $1 \%$ 添 加した。なお，目標とする錠剂特性は，硬度 $50 \mathrm{~N}$ 以上, 崩壊時間 $20 \mathrm{~s}$ 以下とした。

\section{2 造粒装置}

乾粉混合一加水混練一造粒一乾燥を複合化させた連 続混練造粒乾燥システムを用いて, 崩壊錠処方の造粒 を行った。Fig. 2 に連続混練造粒装置（DOME-EX COMBI, ダルトン, 以降 DOME-EX と略称）の外観写 真を示し, Fig. 3 に混練部および造粒部の模式図を示 す。最上部に高速回転する大型チョッパ（先端半径 39 $\mathrm{mm}, \operatorname{Max} 7200 \mathrm{rpm}$ ) を備えた水平型擋找混合機（スパ ルタンミキサ：容器容量 $1.6 \mathrm{~L}$ ）を配置する。混合粉は 下側の容器に排出され, 混合粉が偏析しないよう少量の 粉体を一時的に貯槽し（全容量 $2.8 \mathrm{~L}$ )，スクリュフィー ダにより混練部に混合粉を定量供給する。混練部では水

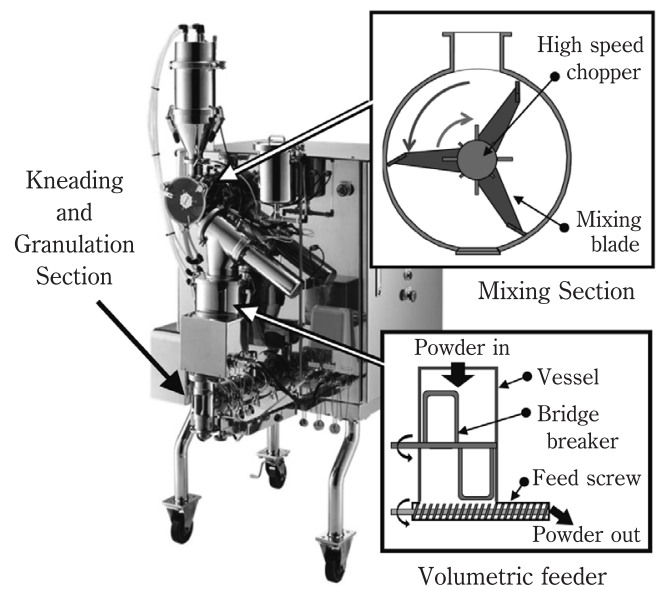

Fig. 2 External view of continuous granulation system (DOME-EX)

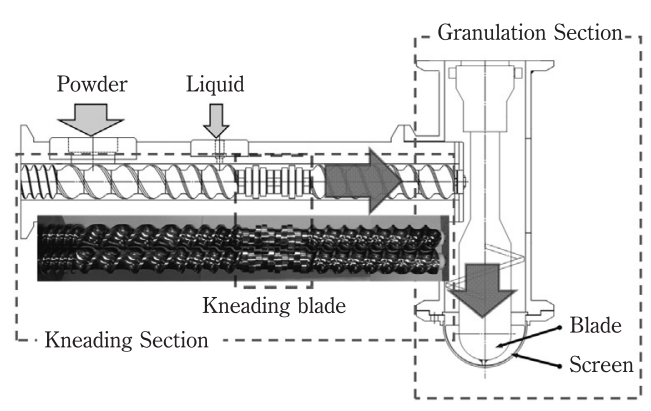

Fig. 3 Experimental set-up of continuous kneading and granulation section

平 2 列に配置されたスクリュ（外径 $23 \mathrm{~mm}$, 全長 300 $\mathrm{mm}$ ）が同一方向に回転し，一定量で供給される粉体と 結合液を混練して前方へ搬送する。混練の度合いは混練 羽根の組数と回転速度により調整することができる。造 粒部に送られた湿潤粉体は重力によって内径 $56 \mathrm{~mm}$ の 垂直円筒内下側に移動し, 最下端に設置された半球状の スクリーン（穴径 $3 \mathrm{~mm}$ ） と垂直に配置された造粒羽根 （最高回転数 $800 \mathrm{rpm}$ ）によって造粒（整粒）され排出 される。

Fig. 4 に連続乾燥装置 (DG-Dryer, ダルトン, 以後 DG-Dryer と略称）の模式図を示す。DG-Dryerは DOME-EX からの湿潤造粒物を熱風で空気輸送する間 に乾燥する連続気流式乾燥機である。1 次乾燥部では過 熱圧縮空気により造粒物の表面を瞬間的に乾燥し, 造粒 物同士の凝集を防ぐ。2 次乾燥部では大量の熱風を追加 し, 螺旋構造の経路を輸送して乾燥する。乾燥した造粒 物は螺旋構造の内部に配置したサイクロンにて捕集され, 製品として取り出される。 


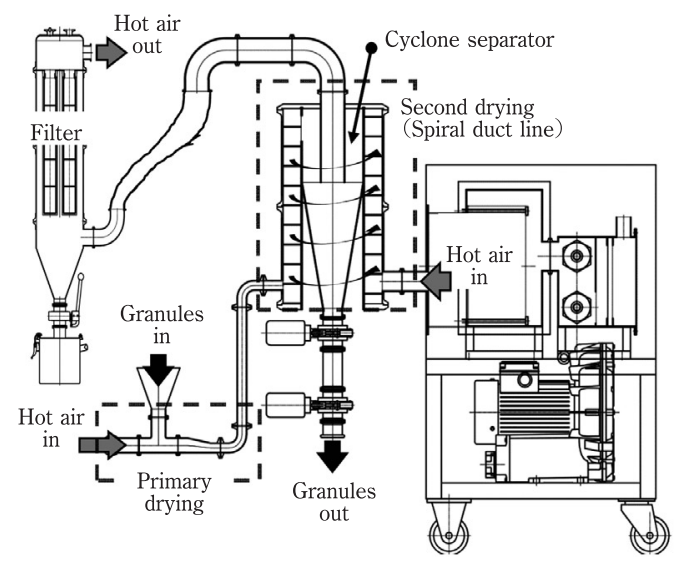

Fig. 4 Schematic diagram of air flow type dryer (DG-Dryer)

DOME-EX と DG-Dryer を組み合わせたシステムに より乾粉混合一加水混練一造粒一乾燥を連続的に処理で きる。

DOME-EX の運転条件は乾粉混合のチョッパ回転速 度 $6500 \mathrm{rpm}$, ミキシング回転速度 $42 \mathrm{rpm}$, 混合時間 $3 \mathrm{~min}$, 定量供給機の粉体供給速度 $3.0 \mathrm{~kg} / \mathrm{h}$, 混練回転 速度 $120 \mathrm{rpm}$, 造粒回転速度 $400 \mathrm{rpm}$ を基本条件とし, 変更のある場合は記述する。また乾燥機DG-Dryerの運 転条件は 1 次乾燥では風量 $0.25 \mathrm{~m}^{3} / \mathrm{min}$, 熱風温度 373 $\mathrm{K}$, 二次乾燥では風量 $2.0 \mathrm{~m}^{3} / \mathrm{min}$, 熱風温度 $353 \mathrm{~K}$ とし た。造粒品を運転開始後 5 ２5分の間でサンプリング し, 物性の評価を行った。

\section{3 混練部の帯留時間とホールドアップ量の測定}

混練部における粉体の滞留時間及びホールドアップ量 を測定した。トレーサとして食用青色 1 号色素（三栄源 F.F.I.）を用いた。

滞留時間の測定手順を以下に示す。粉体供給口から粉 体試料を供給し, 液供給口から精製水を供給しながら青 色色素粉末 $5.0 \mathrm{mg}$ を粉体供給口から瞬時に投入し,こ の時刻を経過時間 $t=0$ とした。その後 5 秒間隔にて混 練排出部から排出される湿潤粉体をサンプリングした。 なお，混練部の排出を定常にするため，混練を始めて 5 分経過した後に青色色素粉末を投入した。粉体供給速度 は $3 \mathrm{~kg} / \mathrm{h}$, 結合液添加率は粉体試料に対して $20 \%$ (D.B.) とした。次にサンプリングにより得られた粉体は $353 \mathrm{~K}$ の恒温槽にて十分に乾燥し, 乳鉢にて粉砕し均一に混合 した。粉砕した粉末 $0.50 \mathrm{~g}$ を $50 \mathrm{~g}$ の水に溶解させ, 濾 紙で不純物を取り除き水溶液を調製した。得られた水溶 液中の青色一号の吸光度を紫外可視分光光度計 (島津製 作所製：UV-1800, 検出波長：630 nm）にて濃度を測定

Vol. 53 No. 9 (2016)

( 49$)$
した。

ホールドアップ量の測定は混練開始から 5 分経過後, 粉体試料と精製水の供給および混練装置の運転を同時に 停止させ, 混練部内に充填されている粉体と液体を合わ せた質量を測定した。

\section{4 錠剤作製および錠剂評価}

得られた造粒物にステアリン酸マグネシウムを添加 し, ビニール袋にて 1 分間予備混合し, ロータリ打錠機 （HT-P18：烟鐵工所）にて $180 \mathrm{mg}, \phi 8 （ \mathrm{R} 12 ） の$ 錠剂 を打錠圧 $10 \mathrm{kN}$ にて作製した。得られた錠剂は日本薬局 方に基づき, 錠剂硬度, 摩損度および崩壊時間を評価し た。

\section{3. 実験結果と考察}

\section{1 固液充填状態}

種々の粉体材料を用いて固液充填状態を表す結合液添 加率と擋拌トルクの関係を調べた結果を Fig. 5 に示す。 図中に記載した質量はMTRの擋挥容器に投入した粉体 試料それぞれの質量である。いずれの粉体試料において も結合液添加率の増加とともに擋汼トルクは増加し, そ れぞれピークを示した。このピークは塑性限界を表すこ とが多い。ここで塑性限界とは粉体・液体・空気の充填 様式によって定義されるファニキュラー域とキャピラ リ一域の境界を表す。さらに結合液添加率が増加しスラ リー域になるとトルクは低下する。なお，押出し造粒や 転動造粒ではキャピラリー域までの結合液添加率を用い ることが多い5 をPL（Plasticity limit）值と呼び, 次式で表される。

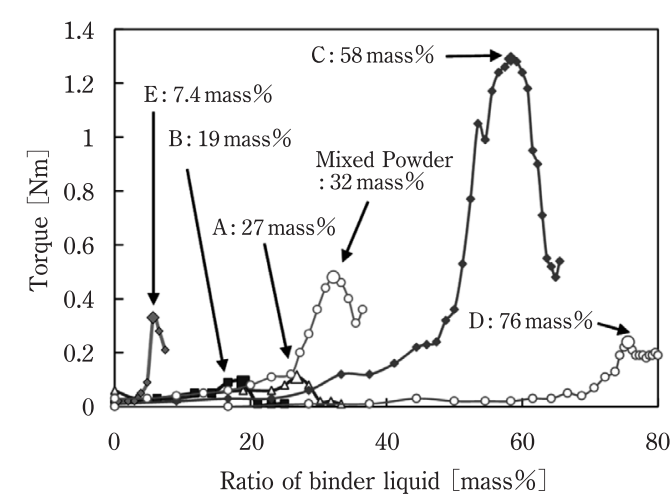

Fig. 5 Relationship between ratio of binder liquid and torque A : Acetaminophen : $30 \mathrm{~g}$

B : D-mannitol : 30g

C : Crystalline cellulose $(\mathrm{KG}-802): 20 \mathrm{~g}$

D : Crystalline cellulose (L-HPC) : $10 \mathrm{~g}$ E : Hydroxypropyl cellulose (HPC-L) : 10g Mixed Powder : 30g 


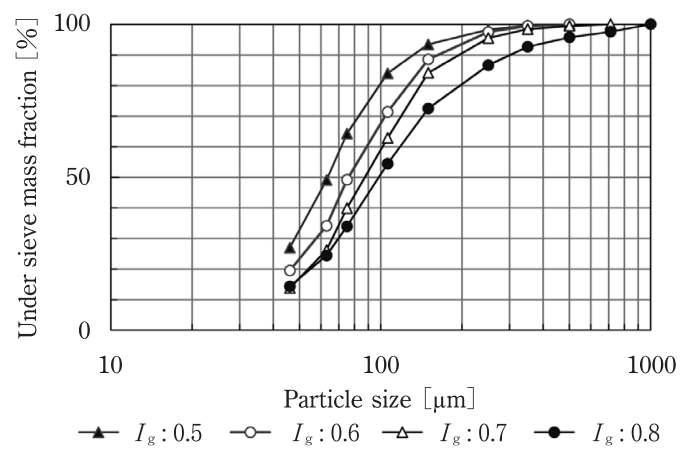

Fig. 6 Particle size distribution at different $I_{g}$

PL 值 $[$ mass \% $]=$ 液体質量 $/($ 粉体+液体質量 $)$

図より，CとDの結晶セルロースの PL 值が大きく, 結晶セルロースの保水率は高いことがわかる。また， C の結晶セルロースのトルク值は高く, 凝集力が高いこと が推察される。崩壊錠処方の混合粉においては結合液添 加率 26 mass\%から急激にトルクが増加し PL 值が 32 mass\%でトルクも大きな值になっていることがわかる。

\section{1.1 造粒評価 $\left(\boldsymbol{I}_{\mathrm{g}}\right)$}

$$
I_{\mathrm{g}}=\text { 任意の結合液添加率 } / \mathrm{PL} \text { 值 }
$$

凝集指数 $I_{\mathrm{g}}$ は上の式で表され，造粒現象を生じる条 件は $I_{\mathrm{g}}<1$ となる。また, 一般に造粒を目的とした場合 における $I_{\mathrm{g}}$ の值は $0.5 \sim 0.85$ の範囲であることが知られ ている ${ }^{6)}$

$I_{\mathrm{g}}=0.5, \quad 0.6, \quad 0.7,0.8 の 4$ 条件で造粒を行い, 造粒物 の顆粒特性（粒子径分布, かさ密度）之錠剤特性（錠剤 硬度，崩壊時間，摩損度）を評価した。

ここで凝集指数 $I_{\mathrm{g}}=0.5,0.6,0.7,0.8$ は結合液添加率 $16.0 ， 19.2 ， 22.4 ， 25.6$ mass\%にそれぞれ相当する。

Fig. 6 に凝集指数 $I_{\mathrm{g}}$ を変化させた際の粒子径分布の 変化を示す。図より $I_{\mathrm{g}}$ が増加するにつれ $350 \mu \mathrm{m}$ より小 さい粒子の割合が減少していることがわかる。錠剤を目 的とした造粒としては粗粒子の割合が少ないことが望ま れることから， $I_{\mathrm{g}} \leqq 0.7$ での造粒が適していることがわ かる。Fig. 5 より $I_{\mathrm{g}}=0.8$ はトルクが急激に上昇する結 合液添加率で，固液充填状態はキャピラリー域であると 思われる。これより, DOME-EXによる造粒はファニ キュラー域が適していると思われる。

Fig. 7 にゆるみかさ密度 $V_{0}$ および压縮度と $I_{\mathrm{g}}$ の関係 を示す。ここで圧縮度は $V_{0}$ とかためかさ密度 $V_{\mathrm{f}}$ より 以下の式で求められる流動性を示す指標であり，小さな

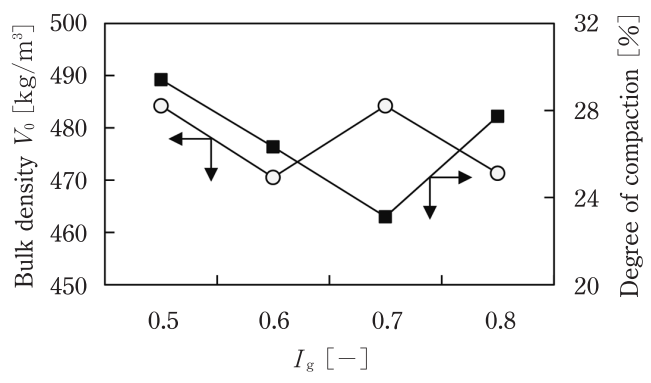

Fig. 7 Effect of $I_{\mathrm{g}}$ on bulk density and degree of compaction

Table 1 Properties of tablet at different $I_{\mathrm{g}}$

\begin{tabular}{cccc}
\hline $\begin{array}{c}I_{\mathrm{g}} \\
{[-]}\end{array}$ & $\begin{array}{c}\text { Tablet Hardness } \\
{[\mathrm{N}]}\end{array}$ & $\begin{array}{c}\text { Friability } \\
{[\%]}\end{array}$ & $\begin{array}{c}\text { Disintegration time } \\
{[\mathrm{s}]}\end{array}$ \\
\hline 0.5 & 50.5 & 0.31 & 16.5 \\
0.6 & 58.5 & 0.23 & 17 \\
0.7 & 68.7 & 0.30 & 21 \\
0.8 & 54.4 & 0.39 & 20.5 \\
\hline
\end{tabular}

值ほど流動性が良いことを表す。

$$
\text { 圧縮度 }=\left(V_{0}-V_{\mathrm{f}}\right) / V_{0}
$$

四より $I_{\mathrm{g}}$ の值に寄らず $V_{0}$ は $500 \mathrm{~kg} / \mathrm{m}^{3}$ 以下である。 圧縮度は $I_{\mathrm{g}}=0.7$ において最小であり, 流動性の良い粉 体であることがわかる。

\section{1. 2 打錠評価 $\left(I_{\mathrm{g}}\right)$}

Table 1 に $I_{\mathrm{g}}$ を変化させて得られた造粒物を用いて調 製した錠剂の特性を示す。錠剤硬度は $I_{\mathrm{g}}$ の增加ととむ に増加して0.7で最大值を示し, その以上では減少に転 じた。この傾向は造粒物の圧縮度とむ相関があった (Fig. 7 参照)。すなわち, 流動性の良い造粒物ほど高 い錠剂硬度となる傾向を示した。また，崩壊時間も $I_{\mathrm{g}}$ の増加とともに増加し $0.7 て ゙$ 最大值を示した。なお, 摩 損度と $I_{\mathrm{g}}$ との間には明確な相関は見られなかった。以 上より所期の目標（硬度 $50 \mathrm{~N}$, 崩壊時間 $20 \mathrm{~s}$ 以下）を 考慮すると, 本実験範囲内では $0.5 \leqq I_{\mathrm{g}} \leqq 0.6$ の条件が適 当とみなせた。

\section{2 混練部内での滞留時間分布とホールドアップ量}

トレーサのパルス入力に対する混練部出口での応答曲 線「トレーサ排出割合 $E(t)$ と時間 $t$ と関係」の测定結 果を Fig. 8 および Fig. 9 に示した。ここで, $E(t)$ はト レーサ濃度を $C_{\mathrm{L}}(t)$ とすると次式で表される。

$$
E(t)=\frac{C_{\mathrm{L}}(t)}{\int_{0}^{\infty} C_{\mathrm{L}}(t) \mathrm{d} t}
$$

Fig. 8 は混練回転速度を変化させた場合である。図よ 


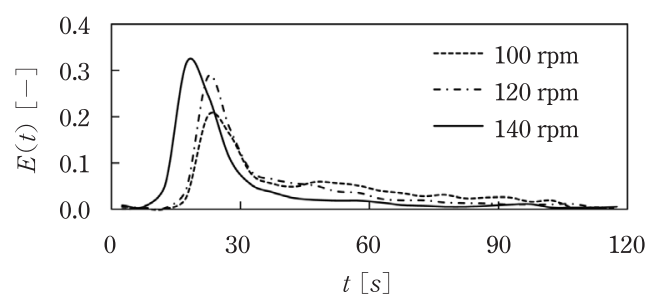

Fig. 8 Temporary changes of $E(t)$ at different rotational speeds

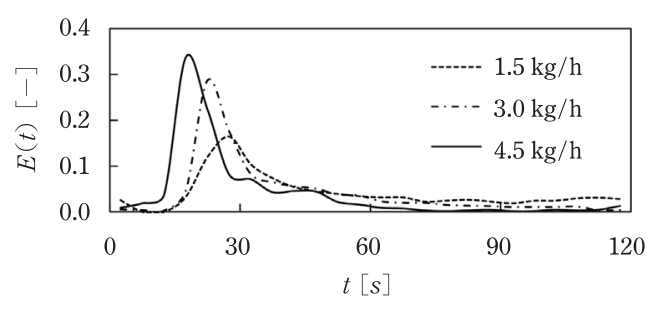

Fig. 9 Temporary changes of $E(t)$ at different feeding rates

り混練回転速度が速いほどトレーサの排出が始まるまで の時間が短く, 短時間に多くのトレーサが排出されるこ とがわかる。

Fig. 9 は粉体供給速度を変化させた場合である。図よ り, 粉体供給速度が速いほどトレーサの排出が開始され るまでの時間が短く短時間に多くのトレーサが排出され

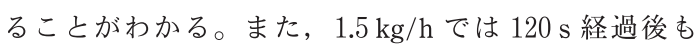
$E(t)$ が 0 に収束していない。このことから粉体供給速 度を遅くすると混練部内部の充填率が低くなり, 後から 投入された粉体が付着した粉体を除去せず，付着の無い 空間を通過して排出される現象が起きていると思われ る。連続造粒で重要となる理想的なピストンフロー（押 し出し流れ）ができていないことになる。つまり，混練 回転速度については $100 \mathrm{rpm}$ 以上で, 粉体供給速度につ いては $3 \mathrm{~kg} / \mathrm{h}$ 以上で理想的なピストンフロー（押し出 し流れ）ができることがわかった。また，Fig. 8 および Fig. 9 の比較より, 混練回転速度を速くすることは粉体 供給速度を速くすることと同様の傾向を示すことがわか る。

平均帯留時間 $\bar{t}$ は次式を用いて算出した。

$$
\bar{t}=\int_{0}^{\infty}(t \cdot E(t)) \mathrm{d} t
$$

混練回転速度と平均滞留時間およびホールドアップ量の 関係を Fig. 10 に，粉体供給速度と平均滞留時間および ホールドアップ量の関係を Fig. 11 にそれぞれ示す。

Vol. 53 No. 9 (2016)

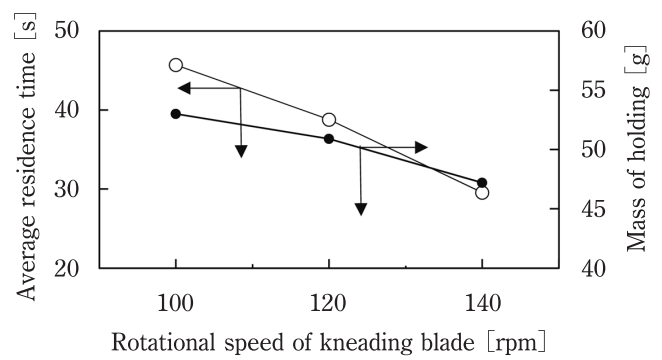

Fig. 10 Effect of rotational speed of kneading blade on average residence time and mass of holding

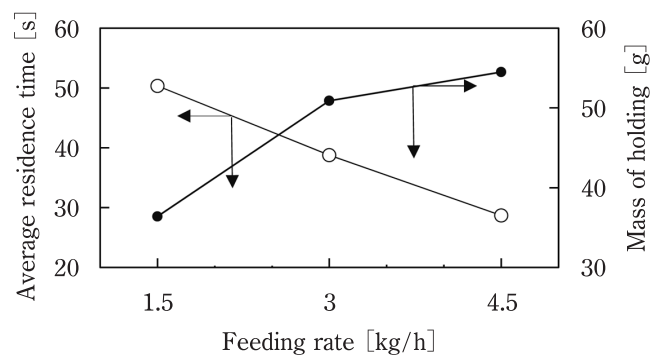

Fig. 11 Effect of feeding rate on average residence time and mass of holding

Fig. 10 より, 混練回転速度の増加とともに平均滞留 時間は短くなり，ホールドアップ量は少なくなることが わかる。スクリュによる推進力の効果が大きく, 混練部 内部の粉体の充填が「疎」になることが推察される。 Fig. 11 より, 粉体供給速度が速いほど平均滞留時間は 短くなり，ホールドアップ量が大きくなった。混練部の 内部の粉体の充填が「密」になり粉体が後から投入され た粉体に押されて排出されることで平均滞留時間が短く なると考える。

以上の結果, 混練回転速度を速くすることと粉体供給 速度を速くすることは平均滞留時間を短くすることは共 通するが, 混練部内部の粉体の充填の疎密の状態に違い がでることがわかった。

\section{2. 1 造粒評価（混練回転速度, 粉体供給速度）}

Fig. 12, Fig. 13 に混練回転速度, Fig. 14, Fig. 15 に粉体供給速度を変化させて造粒し, 得られた造粒物の 粒子径分布とかさ密度と圧縮度をそれぞれ示す。

まず粒子径分布を見ると Fig. 12 より, 混練回転速度 が速いほど微粉の割合が少なくなり，平均粒子径が大き くなるが $350 \mu \mathrm{m}$ 以上の粗粒子の割合は微増であること がわかる。

Fig. 14 において粉体供給速度 $3.0 \mathrm{~kg} / \mathrm{h}$ と $4.5 \mathrm{~kg} / \mathrm{h}$ の 2 つの結果を比較すると, 粉体供給速度が速いほど粒子 径は大きくなり微粉の割合が少なくなるが，一方で 350 


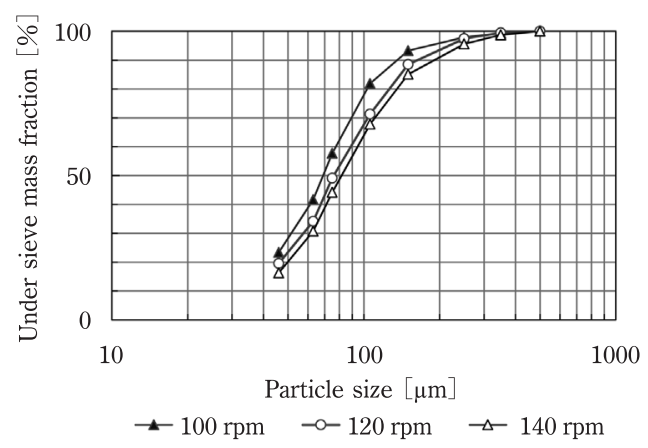

Fig. 12 Particle size distribution at different rotational speeds of kneading blade

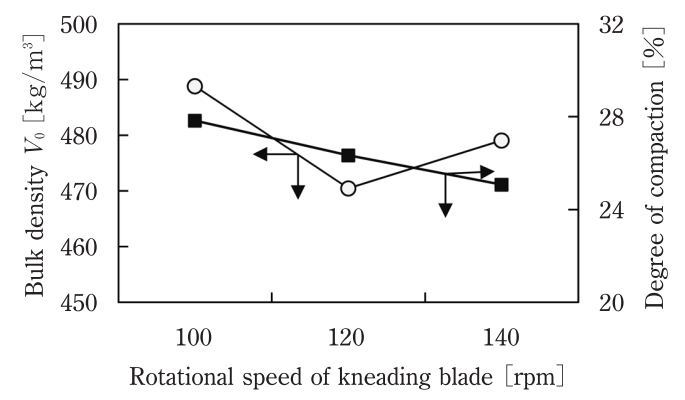

Fig. 13 Effect of rotational speed of kneading blade on bulk density and degree of compaction

$\mu \mathrm{m}$ 以上の粗粒子の割合は微増となった。

次にかさ密度と圧縮度を見ると Fig. 13 より, 混練回 転速度が速いほど圧縮度は小さくなることがわかる。

また, Fig. 15 より回転速度が増加すると圧縮度は小 さくなることがわかる。

我々の知見として，顆粒特性を向上するには結合液の 分散の改善を考え, 混練時間の延長または粉体供給速度 の低下により単位質量あたりの混練に掛かるエネルギー を増やすようにする。しかし，この結果は我々の知見と は逆であることから，混練に掛かるエネルギーは単なる 結合液の分散だけでなく原料粉体に別影響を与え，顆粒 特性を必ずしも良くできないようである。

以上より，本検討に用いた処方においては混練回転速 度が速く, 粉体供給速度が速い方が得られる造粒物の圧 縮度が小さく，流動性は良くなることがわかった。

\section{2. 2 錠剂評価（混練回転速度，粉体供給速度）}

混練回転速度と粉体供給速度を変化させて得られた造 粒物を用いて調製した錠剂の特性を Table 2 と Table 3 にそれぞれ示す。

すべての条件で目標とする錠剂を得ることができるこ とがわかった。混練回転速度を速くする，むしくは粉体 供給速度を速くすると錠剂硬度は大きくなる。また，圧

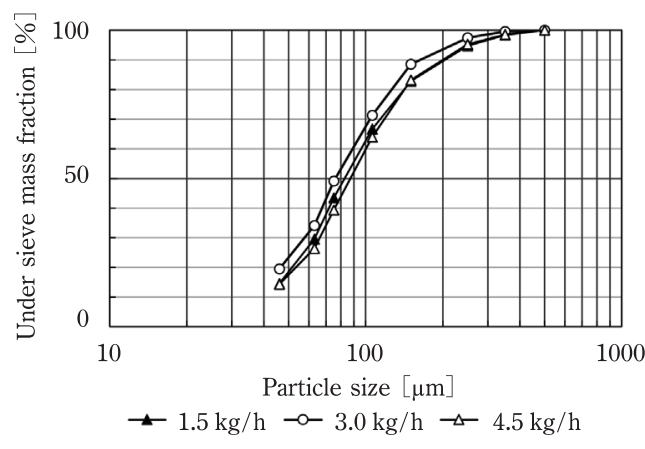

Fig. 14 Particle size distribution at different feeding rates

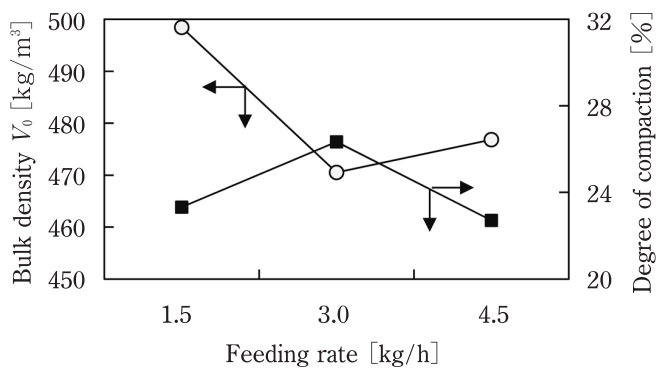

Fig. 15 Effect of feeding rate on bulk density and degree of compaction

Table 2 Properties of tablet at different rotational speeds of kneading blade

\begin{tabular}{cccc}
\hline $\begin{array}{c}\text { Rotational speed of } \\
\text { kneading blade } \\
{[\mathrm{rpm}]}\end{array}$ & $\begin{array}{c}\text { Tablet } \\
\text { Hardness } \\
{[\mathrm{N}]}\end{array}$ & $\begin{array}{c}\text { Friability } \\
{[\%]}\end{array}$ & $\begin{array}{c}\text { Disintegration } \\
\text { time } \\
{[\mathrm{s}]}\end{array}$ \\
\hline 100 & 57.3 & 0.21 & 16.5 \\
120 & 58.5 & 0.23 & 17 \\
140 & 66.6 & 0.21 & 17 \\
\hline
\end{tabular}

Table 3 Properties of tablet at different feeding rates

\begin{tabular}{cccc}
\hline $\begin{array}{c}\text { Feeding rate } \\
{[\mathrm{kg} / \mathrm{h}]}\end{array}$ & $\begin{array}{c}\text { Tablet } \\
\text { Hardness } \\
{[\mathrm{N}]}\end{array}$ & $\begin{array}{c}\text { Friability } \\
{[\%]}\end{array}$ & $\begin{array}{c}\text { Disintegration } \\
\text { time } \\
{[\mathrm{s}]}\end{array}$ \\
\hline 1.5 & 58.3 & 0.18 & 15 \\
3.0 & 58.5 & 0.23 & 17 \\
4.5 & 64.3 & 0.26 & 18 \\
\hline
\end{tabular}

縮度が小さい，つまり流動性の良い造粒物を用いて調製 すると錠剤硬度が大きくなることがわかる。

\section{4. 結言}

新規に開発した連続混合混練造粒乾燥システムを用い て, 凝集指数 $I_{\mathrm{g}}$ を算出し結合液添加率を変化させたと ころ， $0.5 \leqq I_{\mathrm{g}} \leqq 0.6$ において良好な顆粒特性と錠剂特性 
が得られた。連続混練造粒乾燥システムにおいても他の 造粒方式と同様に $I_{g}$ 值で造粒における結合液添加率条 件を設計することにより，目的とした顆粒および錠剤が 得られることが示唆された。

混練部における滞留時間及びホールドアップ量を測定 することにより，理想的なピストンフローが可能な運転 条件を明らかにし，得られる顆粒抢よび錠剂の特性に与 える影響がわかった。本検討に用いた処方においては,
混練部の混練回転速度を速くする, むしくは粉体供給速 度を速くすることで滞留時間が短くなり，良好な硬度と 速やかに崩壊する錠剤が得られることがわかった。

今回検討したパラメータの変更は CMA として挙げら れる粒子径と錠剂硬度に影響を与えた。この結果は CPP の特定，また実験計画法を用いたデザインスペー スの構築に有益であることが示唆された。

\section{References}

1) Singh, R., A. Sahay, F. Muzzio, M. Ierapetritou, R. Ramachandran: "A Systematic Framework for Onsite Design and Implementation of a Control System in a Continuous Tablet Manufacturing Process", Computers and Chemical Engineering, 66, 186-200 (2014)

2) Murakami, K.: "Youten wo wakariyasuku manabu PIC/S GMP Annex15”, Science and Technology Co., Ltd.

3 ) Ministry of Health, Labor and Welfare, Japan : "ICH Pharmaceutical Development Q8(R2) [PFSB/ELD Notifica- tion No. 0628-1]" (2010)

4) Terashita, K., K. Miyanami, T. Konishi and J. Yoshida : "Effect of Tensile Strength on Torque for Wet-powder Mixing”, J. Soc. Mat. Sci., Japan, 30, 873-877 (1981)

5 ) Association of Powder Process Industry and Engineering: "Zouryu Hand Book", pp. 15-16, Ohm Sha, (1991)

6 ) Association of Powder Process Industry and Engineering: “Zouryu Hand Book”, p. 92, Ohm Sha (1991) 